\title{
The influence of sucking habits on occlusion development in the first 36 months
}

Edson Theodoro dos Santos Neto', Adauto Emmerich Oliveira², Rodrigo Walter Barbosa ${ }^{3}$, Eliana Zandonade ${ }^{4}$, Zilda Fagundes Lima Oliveira ${ }^{5}$

Objective: The objective of this study was to identify the influence of sucking habits on the occlusal characteristics of the deciduous dentition.

Methods: The initial sample consisted of 86 infants, aged 0 to 3 months. Seven home visits were performed, when and information on breastfeeding practice, nutritive and non-nutritive sucking habits, mouth breathing and dentition development was collected. From the first sample, impressions of the dental arches were obtained from 58 children at the age of 36 months (+2.51SD). Dental casts were obtained and two examiners, trained and calibrated by the Kappa and Pearson Correlation tests, measured several parameters of dental occlusion, such as arch length, depth, and width.

Results: The results showed that bottle feeding before 6 months was associated to an increased mandibular intermolar width ( $\mathrm{p}=0.01)$. Pacifier use before 6 months was statistically associated to a reduction of the maxillary intercanine $(\mathrm{p}=0.03)$ and intermolar $(\mathrm{p}=0.03)$ width. In addition to these findings, the increased molar depth of the maxillary arch was associated to loss of lip closure before the age of 12 months $(\mathrm{p}=0.03)$.

Conclusion: According to these results, it could be concluded that sucking habits interfere with the determination of some deciduous occlusal characteristics: pacifier sucking limits lateral-lateral maxillary growth, bottle feeding favors lateral-lateral mandibular growth and open bite development, and the lack of lip closure favors the anteroposterior maxillary growth.

Keywords: Morphogenesis. Dental arch. Sucking behavior. Preventive dentistry.

${ }^{1}$ Assistant Professor of Department of Social Medicine, UFES.

${ }^{2}$ Associate Professor of Department of Social Medicine, UFES.

${ }^{3}$ Graduated in Dentistry and MSc in Public Health, UFES.

${ }^{4}$ Associate Professor of Statistics Department, UFES.

${ }^{5}$ MSc in Health Sciences, UFRJ. Professor of Dentistry, Educational Association of Vitória, Brazil.
How to cite this article: Santos Neto ET, Oliveira AE, Barbosa RW, Zandonade E, Oliveira ZFL. The influence of sucking habits on occlusion development in the first 36 months. Dental Press J Orthod. 2012 July-Aug;17(4):96-104.

Submitted: August 07, 2009 - Revised and accepted: April 27, 2011

" The authors report no commercial, proprietary or financial interest in the products or companies described in this article.

Contact address: Edson Theodoro dos Santos Neto Rua Guilherme Bassine, 97 - São Pedro I - Vitória/ES - Brazil CEP: 29.030-015- E-mail: edsontheodoro@uol.com.br 


\section{A influência dos hábitos de sucção no desenvolvimento oclusal nos primeiros 36 meses}

Edson Theodoro dos Santos Neto', Adauto Emmerich Oliveira², Rodrigo Walter Barbosa ${ }^{3}$, Eliana Zandonade ${ }^{4}$, Zilda Fagundes Lima Oliveira ${ }^{5}$

Objetivo: a proposição do estudo foi verificar a influência dos hábitos de sucção nas características oclusais da dentição decídua.

Métodos: o grupo inicial constituiu-se de 86 bebês com idade de 0 a 3 meses. Sete visitas domiciliares foram realizadas, quando informações sobre a prática da amamentação, hábitos de sucção nutritivos e não-nutritivos, respiração bucal e desenvolvimento da dentição foram coletados. A partir do grupo inicial, 58 crianças foram moldadas em consultório na idade média de $36 \pm 2,51$ meses. Modelos de estudo foram obtidos e medidos diversos parâmetros da oclusão dentária, tais como profundidade, extensão e largura das arcadas, por dois examinadores comprovadamente calibrados pelo teste de concordância Kappa e correlação de Pearson.

Resultados: os resultados demonstraram que o aleitamento artificial por mamadeira antes dos 6 meses esteve associado à largura intermolares inferior $(\mathrm{p}=0,01)$. A sucção de chupeta antes dos 6 meses foi estatisticamente associada à diminuição da largura intercaninos superior $(\mathrm{p}=0,03)$ e intermolares superior $(\mathrm{p}=0,03)$. Somando-se a isso, o aumento da extensão molar da arcada superior associou-se à perda do vedamento labial antes dos 12 meses de vida ( $\mathrm{p}=0,03)$.

Conclusão: é possível concluir-se que os hábitos de sucção interferem na determinação de características oclusais na dentição decídua. A sucção de chupeta limita o crescimento da arcada superior; o uso de mamadeira favorece o crescimento laterolateral da mandíbula e o desenvolvimento da mordida aberta; e a ausência de vedamento labial favorece o crescimento maxilar anteroposterior.

Palavras-chave: Morfogênese. Arcada dentária. Comportamento de sucção. Odontologia preventiva.

${ }^{1}$ Professor Assistente do Departamento de Medicina Social, UFES.

${ }^{2}$ Professor Associado do Departamento de Medicina Social, UFES.

${ }^{3}$ Graduado em Odontologia e Mestrando em Saúde Coletiva, UFES.

${ }^{4}$ Professora Associada do Departamento de Estatística, UFES.

${ }^{5}$ Mestre em Ciências da Saúde, UFRJ. Professora de Odontologia, Associação Educacional de Vitória.

\footnotetext{
Como citar este artigo: Santos Neto ET, Oliveira AE, Barbosa RW, Zandonade E, Oliveira ZFL. The influence of sucking habits on occlusion development in the first 36 months. Dental Press J Orthod. 2012 July-Aug;17(4):96-104.

Enviado em: 07 de agosto de 2009 - Revisado e aceito: 27 de abril de 2011

» Os autores declaram não ter interesses associativos, comerciais, de propriedade ou financeiros, que representem conflito de interesse nos produtos e companhias descritos nesse artigo.
}

Endereço para correspondência: Edson Theodoro dos Santos Neto R. Guilherme Bassine, 97 - São Pedro I - CEP 29.030-015

Vitória/ES - E-mail: edsontheodoro@uol.com.br 


\section{INTRODUCTION}

The craniofacial growth and development, including muscles, bones and teeth, has been investigated by scientists over the last years. Based on the functional matrix hypothesis of Moss and Salentjin, ${ }^{1}$ one can infer that the breastfeeding process would work as a matrix that provides the biomechanical stimuli ideally necessary for craniofacial development. ${ }^{2,3}$ Conversely, nutritive and non-nutritive suction and oral breathing would also work as inadequate functional matrices, misshaping the bone and muscle structures that will form the dental spaces. ${ }^{4-7}$

In this context, as teeth erupt and get in contact with all the relations already established, visible and transitory or permanent alterations start to appear. These alterations end up causing bone and muscle disorders and malocclusion in the child. ${ }^{8,9}$

Nutritive or non-nutritive sucking habits, besides their proven effect on the child's oral health, interfere with the child's general health status, leading mothers to adopt practices that are deleterious to the health of newborns, such as the reduction of breastfeeding duration, ${ }^{10}$ triggering a series of health risks and also increasing the risk of death. ${ }^{11}$

Malocclusion is a disorder affecting normal development of the occlusion and has a multifactorial etiology. However, not only biological factors, such as nutritive sucking habits (bottle sucking) and nonnutritive sucking habits (pacifier and finger sucking) determine this relation. Tomita et $\mathrm{al}^{12}$ affirmed that some socio-economic determinants, such as mother's employment and the occupation of the person in the household who has the highest income, are also indirectly associated with the higher prevalence of pacifier sucking and malocclusion among preschool children.

However, undoubtedly, the biological determinants have the most direct influence in determining the maxillomandibular occlusal relationships. The study carried out by Carrascoza et $\mathrm{al}^{13}$ investigated the consequences of bottle feeding compared to the orofacial development in breastfed children and found a higher proportion of maxillary atresia among them. In addition, Aznar et al ${ }^{14}$ confirmed that pacifier sucking led to a reduction in maxillary arch length, especially in the canine region.

Concerning the non-nutritive sucking habits, the study conducted by Viggiano et $\mathrm{al}^{15}$ showed that such habits constitute the main factors for the development of altered occlusion/malocclusion and open bite in deciduous teeth, being even more relevant than the type of feeding adopted in the first months of life. Warren and Bishara ${ }^{9}$ suggested that a prolonged bottle sucking habit led to a higher prevalence of posterior crossbite and anterior open bite, whereas finger sucking led to a higher proportion of increased overjet, increase in the maxillary arch depth and also an increase in the anterior open bite.

Loss of lip closure as an important muscle activity also appears to be an important factor in the development of malocclusion. ${ }^{16}$ The occurrence of such phenomenon is strictly associated with the practice of breastfeeding in the first moments of $\operatorname{life}^{17}$ and is characterized as one of the first signs of the onset of mouth breathing. ${ }^{18}$ Jung, Yang and Nahn et al ${ }^{19}$ indicated that the force of closure of the upper lip had a large influence on the angulation of maxillary incisors. Therefore, atrophy due to lack of use of the orbicular oris muscle may have a determining function in craniofacial morphology.

Considering these aspects, the aim of this study was to investigate the influence of sucking habits on the occlusal development by analysis of dental casts of children who were observed from zero to three years of age.

\section{MATERIAL AND METHODS}

This longitudinal study was conducted on a cohort of infants who were observed until the age of 36 months. All infants aged 0 to 3 months residing in two coverage areas at the city of Vitória, ES, Brazil were included. There were 43 infants aged from 0 to 3 months, referred by one family health care unit and other 43 referred by two family health care units. The coverage areas were chosen because of their higher mortality rate than the city's rate, which is 13.49 per 1,000 live births.

The sample size was calculated using the sample size formula in order to estimate a proportion. Data on the size of the population of livebirths in 2001 in the city of Vitória (4521 children) and the prevalence of breastfeeding at the age of 151 to 180 days for the year 1999 (74.8\%, confidence interval 95\% between $72.7 \%$ and $76.8 \%$ ) used in this study were provided by the website http://www.datasus.gov.br. The desired accuracy of $10 \%$ and the significance level of $5 \%$ were 
considered. The sample size found was 73 children. Therefore, the sample of 86 children used allowed a safety margin of $18 \%$ to account for possible losses to follow-up. This loss to follow-up by 28 children occurred due to address change or not being found at home after several attempts, but it did not impair the analysis in this study.

The group included all children aged 0 to 3 months referred by community health agents. These children were then visited from November 2003 to May 2004 until they reached the amount established. During this period, four researchers, all dental students at the Federal University of Espírito Santo, divided in pairs, went to the health units and observed the home visits made by the community health agent in the homes of study subjects. In this first contact, mothers received guidance on how to take care of their babies regarding oral hygiene, oral breathing, nutritive and nonnutritive sucking habits, the importance of exclusive breastfeeding for at least 6 months for the biomechanics of craniofacial morphogenesis, as well as the nutritional, immunological and affective aspects passed on to the infant during this act.

After counseling, the mothers were invited to participate in the research. They received information on the nature of the study and the frequency of consecutive home visits. Without exception, all mothers who were visited accepted the invitation spontaneously. Based on this agreement, they were interviewed to fill out the form and signed an informed consent.

The visits took place according to a schedule (initially every 3 months, later every 6 months) and also served as observational control of the adherence to the guidelines given in the first visit. These observations were made based on the way the mothers behaved towards their babies. At each visit a new form was filled out and a visual clinical examination was carried out in order to observe the changes occurring. Besides, all information given initially was reinforced. The rooms of the house were also analyzed, so that the information given by the mothers was verified.

In an attempt to involve the people who lived with the baby, counseling was given to all people who were present during the home visit. Whenever possible, guidelines were given concerning oral hygiene, removal of dental plaque and tooth brushing of the household children.
Data collection by home visits finished in June 2006, amounting to seven home visits. The study period covered the maximum duration of breastfeeding recommended by the World Health Organization, since the children were $29.4+2.5 \mathrm{sd}$ months old at the end of the study.

Six months later, when the primary dentition occlusion was expected to be established, the children were contacted and their mothers or caretakers were invited to take them to the outpatient pediatric dental clinic of the Federal University of Espírito Santo. Mothers were interviewed again and impressions were taken for dental casts making. A new informed consent was taken because the impression was considered a more invasive procedure.

Breastfeeding duration variables was defined as the number of months during which the child was breastfed, directly from the breast or indirectly, regardless of being fed on solids or liquids. ${ }^{20}$ This variable was defined by asking at each visit whether the child was still being breastfed or not. If not, records were made of when breastfeeding had stopped, and breastfeeding duration was calculated.

The records addressed whether those habits existed during the study period, and how long the habits of finger, pacifier and bottle sucking had been practiced. These variables were defined by asking at each visit whether the child had the habit. If yes, records were made of when it started and, in case the habit had been discontinued, when it had stopped, and duration in months was calculated. In addition, analysis of the frequency of habits was considered according to the daily practice, yet assessment of the intensity of habits was based on the often imprecise information provided by the mothers, to establish the hours spent in the habits.

At each visit the mother was asked about the introduction of any food of any nature in the child's diet (fruit, vegetables, smashed or industrialized). If yes, records were made of the month in which the child had started this eating habit and literally what food had been used during the previous 24 hours.

Lip closure was defined at each visit based on observational analysis and the mother's report. If during the examination the child kept the lips sealed and remained with the mouth closed without continuous contraction of the genial muscle, presence of lip closure was registered. The child was considered as "not 
having lip closure" if during the home visit he or she remained with the mouth open most of the time and when the mother reported that the child remained with the mouth open most of the time.

Alginate (Alvagel ${ }^{\circledR}$ ) and plastic (Morelli ${ }^{\circledR}$ ) impressions were made at the dentist's office, under room temperature $\left(20^{\circ} \mathrm{C}\right)$, and were maintained moistened in individual plastic bags with wet cotton, bite impression was registered in wax. The impressions were sent to a specialized laboratory, where the preparation of casts was standardized, from mechanical mixing of plaster to the trimming of casts, in the occlusion previously recorded.

After the casts were obtained, two trained examiners analyzed the occlusion and performed the occlusion measurements on all 58 casts independently in an office, under room temperature $\left(\sim 20^{\circ} \mathrm{C}\right)$, according to the proposition of Warren and Bishara: ${ }^{9}$

1) Overbite or vertical overlap and overjet or horizontal overlap: the casts were placed on a flat table and the measurements were taken with a caliper (Somet Inox ${ }^{\circledR}$ ) and a $0.5 \mathrm{~mm}$ mechanical pencil (Pentel ${ }^{\circledR}$ ).

2) Anterior open bite was registered with the lack of vertical overlap between any of the maxillary and mandibular incisors, without estimating the open bite dimension.

3) Posterior crossbite was registered when two or more posterior teeth, also including the canines, presented an occlusal problem in which the buccal cusps of the maxillary teeth occluded lingually in relation to the buccal cusps of the mandibular teeth. The study considered either unilateral or bilateral posterior crossbites as well as functional crossbites, observed by a displacement of the mandible.

4) Dental arches were classified as follows: type I, when the diastemata were generalized in both arches; and type II, when only primate spaces occurred.

5) The terminal relationship of the deciduous second molar was classified in mesial step, when there was maxillary projection; distal step, when there was mandibular projection; and edge-to-edge relationship when the maxillary and mandibular molars coincided.

6) The lengths of the maxillary and mandibular arches were taken using the Dentaurum ${ }^{\circledR}$
030395 dry-point drawing compass and a caliper (Somet Inox ${ }^{\circledR}$ ) by the addition of 4 consecutive manual measurements which were taken by placing the compass and the caliper on the bone base of each dental quadrant: from the most distal region of the deciduous second molar to the most mesial region of the canine; and from the most mesial region of the canine to the most mesial region of the central incisor.

7) The measurements of maxillary and mandibular intercanine and intermolar widths were performed using the dry-point drawing compass and the caliper, by measuring the widths between the canine cusp tips and between the tips of the distobuccal cusps in the maxillary cast and the tips of the intermesio-buccal cusps in the mandibular cast.

8) The measurement of palatal depth or palatal height was performed using a special threedimensional Dentaurum ${ }^{\circledR} 028353$ (Korkhaus) drawing compass by positioning the dry points on the distobuccal cusps of the deciduous second molars, the anterior spacer on the buccal aspect of the maxillary central incisors, and the depth cursor touching the bottom of the palatal vault.

9) The canine and molar depth of the maxillary and mandibular arches was measured by using a cotton string and a caliper by stretching the line more distally bilaterally to the canines and deciduous second molars and measuring up to the most anterior portion of the bone base between the central incisors.

Data were recorded in forms adapted by both researchers, typed in the SPSS for Windows 11.0 statistical program and submitted to Pearson correlation tests for quantitative variables and Kappa test for qualitative variables. Pearson correlation tests showed that the variables measured had a strong and very strong correlation rate, ranging from 0.72 to 0.95 , which is considered by Landis and $\mathrm{Koch}^{21}$ as an excellent standard of correlation. However, the Kappa test did not reveal almost perfect agreement standards, as they were below 0.80. Therefore, in the variables in which these discrepancies were present, the study casts were reassessed and the prevailing diagnosis was chosen by the two examiners together. 
When all doubts concerning the diagnosis were solved, only the data of one examiner - first author of the present study - were used to test hypotheses of association between sucking habits and occlusal characteristics.

The Student t test and chi-square test were used to analyze the associations between each variable of sucking habits and all occlusal characteristics analyzed, at significance levels of $\mathrm{p}<0.05$ and $\mathrm{p}<0.10$.

The research protocol was submitted to the Ethics Committee of the Biomedical Center at UFES and was totally approved in the 43rd ordinary meeting of 25th June, 2003 under CEP registration No. 0020/2003. The informed consent necessary for the study was presented to the parents before development of the research. Authorization for the impression procedure was approved in a new project presented to the aforementioned committee in the ordinary meeting of 28th June, 2006.

\section{RESULTS}

Following the random choice of one of the spreadsheets obtained from data collected by the two examiners, it was possible to carry out not only the description of the diagnostic examinations but also an inferential statistical analysis, which was related to the habitual characteristics of the children collected at study onset.

Table 1 shows the means and standard deviations of measurements. Additionally, the length of the mandibular arch presented the highest standard deviation, showing that this length had the greatest variability among the children studied.

Figure 2 describes the relative frequencies of the diagnoses established. The prevalence of normal standards in the deciduous dentition could be seen, as more than $80 \%$ presented absence of open bite and crossbite, more than $60 \%$ presented arches with type I generalized diastema, and more than $50 \%$ exhibited an edge-to-edge terminal relationship of deciduous second molars.

The significant associations between the measurements taken and the habits of children are shown in Table 2 according to the student t test. In this context, it may be observed that breastfeeding for at least 12 months possibly contributed to the increase of the mean palatal depth in relation to children who were breast-fed for longer periods, yet the analysis did not allow to definitely state this association.

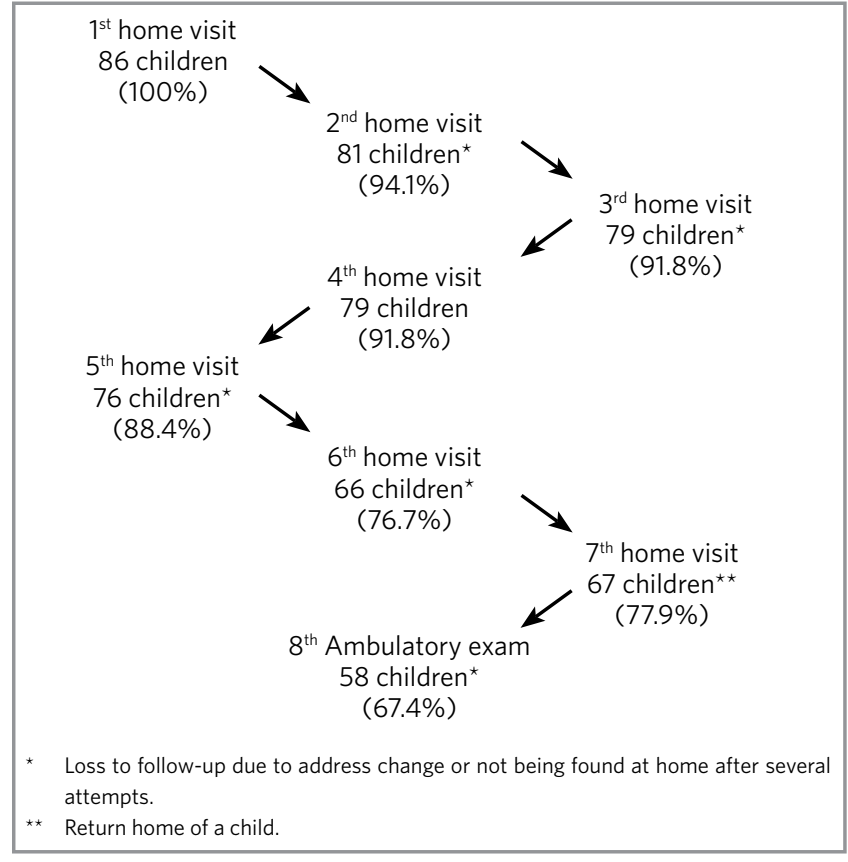

Figure 1 - Cohort dynamics.

Table 1 - Descriptions of measurements in $\mathrm{mm}$ of the dental casts of 36-month-old children, Vitória, Brazil, 2007.

\begin{tabular}{cccc}
\hline Variable & n & Mean & SD \\
\hline Overjet & 58 & 3.0 & 1.7 \\
Overbite & 58 & 2.8 & 1.4 \\
Perimeter of the upper arch & 58 & 74.7 & 4.3 \\
Perimeter of the lower arch & 58 & 67.9 & 2.7 \\
Upper intercanine distance & 58 & 30.3 & 1.9 \\
Lower intercanine distance & 58 & 23.8 & 1.7 \\
Upper intermolar distance & 57 & 43.5 & 2.3 \\
Lower intermolar distance & 58 & 37.2 & 1.9 \\
Palatal depth & 57 & 12.8 & 1.3 \\
Canine extension of upper arch & 58 & 11.8 & 1.6 \\
Canine extension of lower arch & 58 & 7.7 & 1.0 \\
Molar extension of upper arch & 57 & 29.1 & 1.8 \\
Molar extension of lower arch & 58 & 25.2 & 1.7 \\
\hline
\end{tabular}

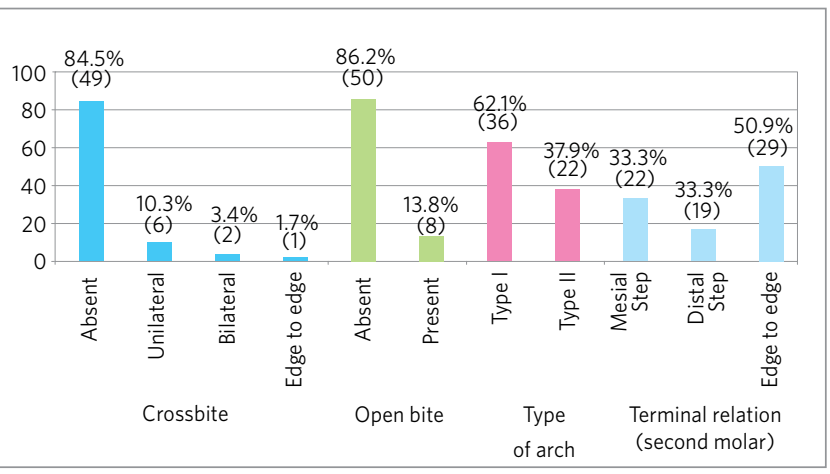

Figure 2 - Relative frequency of occlusal alterations according to analysis of dental casts of 36-month-old children, Vitória, Brazil, 2007. 
However, the increase in the length of the mandibular arch was not associated to the introduction of semi-solid foods before five months of age and bottle feeding before 6 months of age. Moreover, bottle feeding also contributed to the increase in mandibular intermolar widths, and this difference was statistically significant.
The $\mathrm{c}^{2}$ tests of association found only two relevant associations. Bottle feeding before 6 months of age was a statistically significant factor concerning the development of anterior open bite, not associated with the development of type I arch (Tab 3). However, there were very similar proportions of bottle feeding before 6 months of age among children with type II arch.

Table 2 - Student's $t$ test for association between nutritive and non-nutritive sucking habits and the measurements taken from dental casts of 36 -monthold children.

\begin{tabular}{|c|c|c|c|c|c|c|}
\hline Variable & Groups & $\mathbf{n}$ & Mean & SD & Student's $\boldsymbol{t}$ test & p value \\
\hline \multicolumn{7}{|l|}{ Breastfeeding (12 months or more) } \\
\hline \multirow{2}{*}{ Palatal depth } & Yes & 36 & 12.53 & 1.43 & \multirow{2}{*}{-1.90} & \multirow{2}{*}{0.06} \\
\hline & No & 21 & 13.21 & 1.09 & & \\
\hline \multicolumn{7}{|c|}{ Semisolid feeding (before 5 months) } \\
\hline \multirow{2}{*}{ Perimeter of the upper arch } & Yes & 21 & 68.79 & 2.47 & \multirow{2}{*}{1.89} & \multirow{2}{*}{0.06} \\
\hline & No & 37 & 67.43 & 2.70 & & \\
\hline \multicolumn{7}{|l|}{ Pacifier use (before 6 months) } \\
\hline \multirow{2}{*}{ Upper intercanine distance } & Yes & 30 & 29.78 & 1.97 & \multirow{2}{*}{-2.23} & \multirow{2}{*}{$0.03^{*}$} \\
\hline & No & 27 & 30.89 & 1.74 & & \\
\hline \multirow{2}{*}{ Upper intermolar distance } & Yes & 30 & 42.90 & 2.11 & \multirow{2}{*}{-2.19} & \multirow{2}{*}{$0.03^{*}$} \\
\hline & No & 26 & 44.19 & 2.29 & & \\
\hline \multicolumn{7}{|l|}{ Bottle feeding (before 6 months) } \\
\hline \multirow{2}{*}{ Perimeter of the lower arch } & Yes & 38 & 68.33 & 2.71 & \multirow{2}{*}{1.71} & \multirow{2}{*}{0.09} \\
\hline & No & 19 & 67.05 & 2.55 & & \\
\hline \multirow{2}{*}{ Lower intermolar distance } & Yes & 38 & 37.64 & 1.93 & \multirow{2}{*}{2.60} & \multirow{2}{*}{$0.01^{\star}$} \\
\hline & No & 19 & 36.29 & 1.69 & & \\
\hline \multicolumn{7}{|c|}{ Loss of lip sealing (before 12 months) } \\
\hline \multirow{2}{*}{ Overjet } & Yes & 14 & 3.96 & 1.78 & \multirow{2}{*}{2.63} & \multirow{2}{*}{$0.01^{\star}$} \\
\hline & No & 44 & 2.64 & 1.60 & & \\
\hline \multirow{2}{*}{ Molar extension of upper arch } & Yes & 14 & 30.04 & 2.02 & \multirow{2}{*}{2.25} & \multirow{2}{*}{$0.03^{\star}$} \\
\hline & No & 43 & 28.85 & 1.61 & & \\
\hline
\end{tabular}

* Statistically significant values $(p<0.05)$. Other significant values $(p<0.10)$

Table 3 - Chi-square test for association between nutritive and non-nutritive sucking habits and measurements taken from dental casts of 36-month-old children, Vitória-ES, 2007.

\begin{tabular}{|c|c|c|c|c|c|}
\hline \multicolumn{6}{|c|}{ Bottle feeding (before 6 months) } \\
\hline & & Yes & No & $\chi^{2}$ & p value \\
\hline \multirow{4}{*}{ Open bite } & Absent & $32(80 \%)$ & $18(100 \%)$ & \multirow{2}{*}{ Fisher } & \multirow{2}{*}{0.04} \\
\hline & Absent & $8(20 \%$ & $0(0 \%)$ & & \\
\hline & TOTAL & $40(100 \%)$ & $18(100 \%)$ & & \\
\hline & & Yes & No & & \\
\hline \multirow{3}{*}{ Type of arch } & Type I & $28(70 \%)$ & $8(45.5 \%)$ & \multirow{2}{*}{3.44} & \multirow{2}{*}{0.06} \\
\hline & Type II & $12(30 \%)$ & $10(55.5 \%)$ & & \\
\hline & TOTAL & $40(100 \%)$ & 18 & & \\
\hline
\end{tabular}




\section{DISCUSSION}

Conceptually, it is reasonable to think that determination of craniofacial standards, either normal or pathological, is influenced by a wide range of factors which interact resulting in deciduous occlusal morphology. These factors include socioeconomic determinants, breastfeeding and feeding practices, nutritive and non-nutritive sucking habits, respiratory and functional factors, as well as environmental, behavioral and biological-genetic intrinsic factors. ${ }^{12,22}$

As for descriptive aspects, the means of the measurements of intercanine, maxillary molar and mandibular molar widths found in this study are very close to those found by Aznar et al, ${ }^{14}$ whereas the frequencies of crossbite and open bite are similar to those reported by Karjalaimen et al. ${ }^{23}$ Other researchers consider that the intercanine distance is an important factor to anticipate the occurrence of crossbite. ${ }^{24}$

Regarding breastfeeding practices, the association between breastfeeding for 12 months and a reduced palatal depth suggests that breastfeeding is a key element for craniofacial development. In the study carried out by Viggiano et al, ${ }^{15}$ breastfeeding was considered a protective factor to avoid the development of posterior crossbite in the deciduous dentition, whereas Peres et $\mathrm{al}^{22}$ showed that breastfeeding for less than 9 months is a risk factor for the development of open bite. However, Warren and Bishara ${ }^{9}$ compared the palatal depth between four groups according to breastfeeding duration. Within this context, breastfeeding would favor palate formation, thus influencing a harmonious growth of maxillary bones and attenuating the formation of the deep high-arched palate.

The nutritive sucking habits, represented by the variable of bottle feeding before 6 months, were significantly associated with the occurrence of anterior open bite yet were not associated with type I arch, with generalized diastema. However, Viggiano et $\mathrm{al}^{15}$ found that non-nutritive sucking habits, more than the type of food given to children in the first months of life, is the main risk factor for the development of altered occlusion and open bite in deciduous teeth. The study conducted by Charchut, Allred and Needleman suggested that predominant bottle feeding for children aged 12 to 18 mouths was associated with open bite, ${ }^{25}$ whereas Peres et $\mathrm{al}^{26}$ concluded, by a multivariate analysis, that pacifier sucking between 12 months and five years of age and finger sucking appear as risk factors for the development of open bite, becoming risk factors for the development of posterior crossbite when combined with a shorter breastfeeding period.

Aznar et al, ${ }^{14}$ however, found significant association between shorter maxillary intermolar width and bottle feeding compared to children who were not given a bottle. Carrascoza et $\mathrm{al}^{13}$ showed that maxillary atresia was present in $22 \%$ of children who were given the bottle and were also breast-fed. These results evidence the effect of bottle feeding on the maxilla and not on the reduction of mandibular intermolar width and increase of mandibular length, as shown in the present study.

Based on these studies, it can be suggested that bottle feeding can interfere with both dental arches. However, the isolated effect of bottle feeding on craniofacial development is not well defined, which encourages the accomplishment of both experimental and population-based studies.

Other studies correlated thumb sucking and pacifier use and bottle feeding with increased overjet and open bite. ${ }^{16,25}$ This can be explained by the recent shaping of the dental arches which were not exposed long enough to the functional load applied on the teeth during the practice of those deleterious habits. Considering the duration period at 12, 24, 36 and 48 months, Warren and Bishara ${ }^{9}$ found that pacifier and finger sucking habits were associated to the reduction or increase of various mandibular and maxillary measurements.

Regarding pacifier use, its harmful effect on the duration of breastfeeding, which precipitates several consequences for the child's general health status, is suggested from the literature. However, its specific deleterious effect on the occlusal development is noticed mainly in the maxillary dental arch. Aznar et al, ${ }^{14}$ in a study conducted on Spanish children, found that pacifier sucking habit led to a significant reduction of the intercanine and intermolar mean width in the maxillary arch. Very similar results were confirmed in the present study. Warren and Bishara, ${ }^{9}$ however, associated the groups of children who used pacifier for a longer period with a shorter intercanine width in the mandibular arch. Although it was not detected in the present study, pacifier sucking habit is well known in the scientific literature as a risk factor for the 
occurrence of anterior open bite ${ }^{7,9}$ and increased overjet. ${ }^{25}$ This occlusal alteration, in turn, has been associated with the occurrence of deviations in the cervical spine which affect the quality of life of the subject. ${ }^{27}$ As one may notice, the use of pacifier had a direct effect on the maxilla favoring its early narrowing, as observed by the smaller means of maxillary intercanine and intermandibular widths in children who used the pacifier before 6 months of age.

With regard to the influence of respiratory alterations on occlusion, Menezes et $\mathrm{al}^{28}$ studied a sample of one hundred and fifty 8-to-10-year-olds and observed a significant frequency of facial alterations, such as higharched palate and anterior open bite in mouth breathers compared to nose breathers. Aznar et al, ${ }^{14}$ however, concluded that mouth breathing appeared in association with a reduction of the sizes of both arches, and this reduction was more significant in the maxillary intercanine width. Ogaard, Larsson and Lindsten ${ }^{24}$ concluded that pacifier use influences the maxillary and mandibular intercanine distances. However, in the present study, loss of lip closure was considered the earliest sign indicating the onset of mouth breathing, ${ }^{18}$ which was significantly associated with increased overjet and increase in the molar depth of maxillary arch, suggesting the effect of absence of anterior lip closure on the anteroposterior maxillary growth.

Jung, Yang and Nahn et al ${ }^{19}$ indicated that the force of upper lip closure had significant influence on the angulation of the maxillary incisors. Therefore, atrophy due to lack of use of the orbicular oris muscle (loss of lip closure) seems to be an important factor in the development of malocclusions. Variables related to phonetic and functional alterations which can act as co-factors in the determination of dental arches were not considered either. ${ }^{4}$

In face of these considerations, the inclusion of variables related to morphogenetic and functional standards (related to speech and the function of orofacial muscles) would be necessary in order to increase the level of the scope of the study.

Considering these aspects, it is necessary to demonstrate that follow-up studies are rare and difficult to perform, yet provide greater scientific evidence. In addition, this study promotes a new position for early intervention in the oral health of children by preventive strategies to reduce or eliminate mouth habits and consequently avoid malocclusions in permanent dental arches.

\section{CONCLUSIONS}

Nutritive (bottle feeding) and non-nutritive (pacifier use) sucking habits and the loss of lip closure were also associated with occlusal characteristics, even if they were introduced or started at an early age.

The time of initiation and cessation of bottle feeding and the duration of such practices showed evidence of association in the determination of occlusal development.

From these results, it could be concluded that sucking habits interfere with the determination of some deciduous occlusal characteristics: pacifier sucking limits lateral-lateral maxillary growing, bottle feeding favors lateral-lateral mandibular growth and open bite development and the absence of lip closure stimulates the anteroposterior maxillary growth. 


\section{REFERENCES}

1. Moss ML, Salentjin L. The primary role of functional matrices in facial growth. Am J Orthod. 1969;55(6):566-77

2. Linder-Aronson S. Respiratory function in relation to facial morphology and the dentition. British J Orthod. 1979:6(2):59-71.

3. Legovic M, Ostric $L$. The effects of feeding methods on the growth of the jaws in infants. ASDC Journal of Dentistry Children. 1991;58(3):253-5.

4. Hanson ML, Cohen MS. Effects of form an function on swallowing and the development dentition. Am J Orthod. 1973;64(1):63-82.

5. Hannuksela A. The effect of atopy on the dentition. Eur J Orthod. 1983;5(4):279-85.

6. Bishara SE, Kohout FJ, Hogan MM. Influence of feeding and non-nutritive sucking methods on the development of the dental arches: longitudinal study of the first 18 months of life. Pediatr Dent. 1987;9(1):13-21.

7. Farsi NMA, Salama FS. Sucking habits in Saudi children: prevalence, contributing factors and effects on the primary dentition. J Clinic Ped Dent. 1997;19(1):28-33.

8. Venetikidou A. Incidence of malocclusion in asthmatic children. J Clinic Ped Dent 1993;17(2):89-94

9. Warren JJ, Bishara SE. Duration of nutritive and nonnutritive sucking behaviors and their effects on dental arches in the primary dentition. Am J Orthod Dentofacial Orthop. 2002;121(4):347-56

10. Santos-Neto ET, Emmerich AO, Zandonade E, Molina MDCB. Pacifier use as a risk factor for reduction in breastfeeding duration: a systematic review. Rev Bras Saúde Matern Infant. 2008;8(4):377-89.

11. Post CLA, Victora CG, Valente JG, Leal MC, Niobey FML, Sabroza PC. Fatores prognósticos de letalidade hospitalar por diarréia ou pneumonia em menores de um ano de idade: estudo de caso e controle. Rev Saúde Pública. 1992;26(6):369-78.

12. Tomita NE, Sheiham A, Bijella VT, Franco LJ. Relação entre determinantes socioeconômicos e hábitos bucais de risco para más-oclusões em pré-escolares. Pesq Odont Bras. 2000;14(2):169-75.

13. Carrascoza KC, Possobon RF, Tomita LM, Moraes AB. Consequences of bottlefeeding to the oral facial development of initially breastfed children. J Pediatr. 2006;82(5):395-7.

14. Aznar T, Galán AF, Marín I, Domínguez A. Dental arch diameters and relationships to oral habits. Angle Orthod. 2006;76(3):441-5.
15. Viggiano D, Fasano D, Monaco G, Strohmenger L. Breast feeding, bottle feeding, and non-nutritive sucking effects on occlusion in deciduous dentition. Arch Dis Child. 2004;89(12):1121-23.

16. Larsson E. The effect of dummy-sucking on the occlusion: a review. Eur J Orth. 1986;8:127-30.

17. Neiva FCB, Cattoni DM, Ramos JLA, Issler H. Desmame precoce: implicações para o desenvolvimento motor-oral. J Pediatr. 2003;79(1):7-12.

18. Ricketts RM. Respiratory obstruction syndrome. Am J Orthod. 1968;54(7):495-514.

19. Jung MH, Yang WS, Nahm DS. Effects of upper lip closing force on craniofacial structures. Am J Orthod Dentofacial Orthop. 2003;123(1):58-63.

20. World Health Organization. World Health Organization's infant feeding recommendation. Bulletin of World Health Organization. 1995;73:165-74.

21. Landis JR, Koch GG. The measurement of observer agreement for categorical data. Biometrics. 1977;33(1):159-74.

22. Peres KG, De Oliveira LMR, Sheiham A, Peres MA, Victora CG, Barros FC. Socia and biological early life influences on the prevalence of open bite in Brazilian 6year-olds. Int J Paediatr Dent. 2007;17(1):41-9.

23. Karjalainen $\mathrm{S}$, Rönning $\mathrm{O}$, Lapinleimu $\mathrm{H}$, Simell O. Association between early weaning, non-nutritive sucking habits and occlusal anomalies in 3-year-old Finnish children. Int J Paediatr Dent. 1999;9(3):169-73.

24. Ogaard B, Larsson E, Lindsten R. The effect of sucking habits, cohort, sex, intercanine arch widths, and breast feeding on posterior crossbite in Norwegian and Swedish 3-year-old children. Am J Orthod Dentofacial Orthop. 1994;106:161-6

25. Charchut SW, Allred EN, Needleman, HL, The effects of infant feeding patterns on the occlusion of the primary dentition. J Dent Child. 2003;70:197-203.

26. Peres KG, Barros AJ, Peres MA, Victora CG. Effects of breastfeeding and sucking habits on malocclusion in a birth cohort study. Rev Saúde Pública. 2007; 1(3):343-50.

27. Sonnesen L, Kjaer I. Cervical column morphology in patients with skeletal open bite. Orthod Craniofac Res. 2008;11(1):17-23.

28. Menezes VA, Leal RB, Pessoa RS, Pontes RMES. Prevalência e fatores associados à respiração oral em escolares participantes do projeto Santo Amaro - Recife, 2005. Rev Bras Otorrinolaringol. 2006;72(3):394-9. 